\title{
Efekty wszczepienia implantów iris-claw do komory tylnej w oczach bezsoczewkowych z niestabilną torebką - retrospektywne badanie obserwacyjne
}

\section{Outcomes of posterior chamber iris-claw intraocular lenses implantation in aphakic eyes with insufficient capsular support: retrospective observational study}

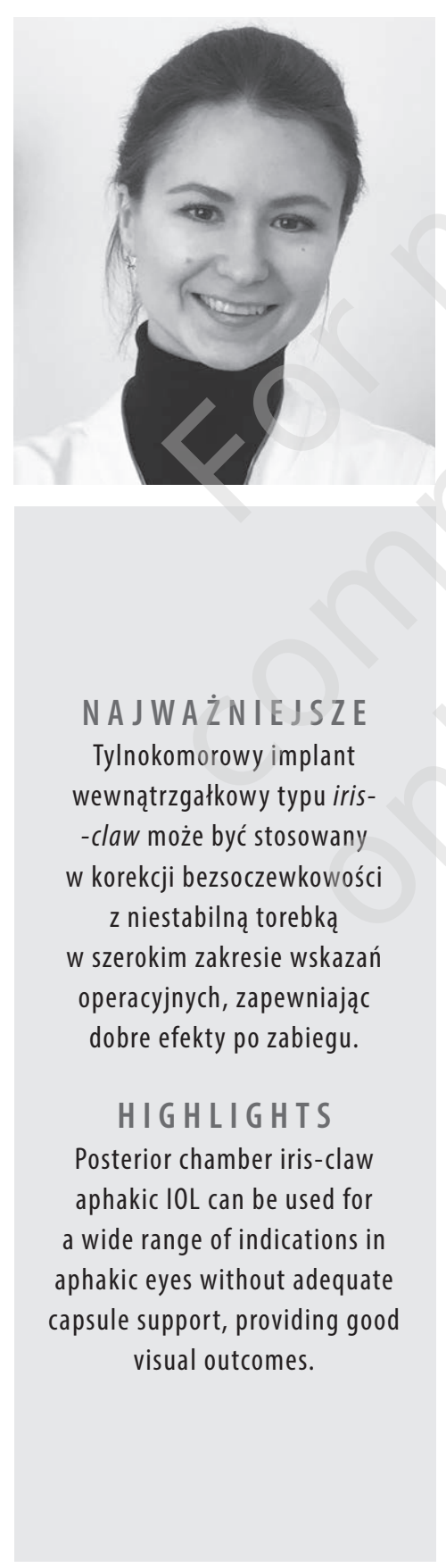

Ilona A. Kaczmarek ${ }^{1}$, Jaromir Wasyluk ${ }^{1,2}$, llona Jędrzejewska ${ }^{2}$,
Małgorzata Myślińska ${ }^{1}$, Marek E. Prost $^{1}$

Klinika Okulistyki, Wojskowy Instytut Medycyny Lotniczej w Warszawie p.o. Kierownika Kliniki: dr n. med. Jaromir Wasyluk ${ }^{2}$ Centrum Okulistyczne OPTIMUM w Warszawie Kierownik medyczny: dr n. med. Małgorzata Krajewska

\section{STRESZCZENIE}

Wprowadzenie: Implantacja soczewek iris-claw jest często stosowaną metodą korekcji bezsoczewkowości z niestabilną torebką. Celem badania była ocena wyników anatomicznych, funkcjonalnych oraz powikłań po zabiegu u pacjentów z afakią i niestabilną torebką soczewki.

Materiał i metody: Do badania włączono 44 oczu (44 pacjentów). Średni wiek: $72,5 \pm 20,5$ lat (18-95 lat). Średni czas obserwacji: 12,11 + 6,02 miesiąca (od 1 do 24 miesięcy). W 5 oczach $(11,36 \%)$ wykonano pierwotne wszczepienie implantu, w 24 oczach $(54,55 \%)$ wymianę implantu tylnokomorowego na soczewkę typu iris-claw, w 15 oczach wtórne wszczepienie implantu.

Wyniki: Końcowa najlepiej skorygowana ostrość wzroku była istotnie statystycznie lepsza niż przed zabiegiem $(0,49 \pm 0,33$ vs 0,36 \pm 0,26 wg Snellena), $(\mathrm{P}<0,05)$. W 40 oczach $(90,91 \%)$ błąd refrakcji na koniec okresu obserwacji był $\mathrm{w}$ granicach $\pm 2 \mathrm{Dsph}$. Istotne powikłania pooperacyjne obejmowały: zapalenie tęczówki 2 oczu (4,55\%), przemieszczenie implantu 2 oczu (4,55\%), torbielowaty obrzęk plamki 6 oczu (13,64\%), odwarstwienie siatkówki 2 oczu (4,55\%), wylew krwi do ciała szklistego 1 oko (2,27\%), zakrzep żyły środkowej siatkówki 1 oko (2,27\%), zapalenie troficzne rogówki 1 oko (2,27\%).

Wnioski: Tylnokomorowe implanty wewnątrzgałkowe typu iris-claw mogą być stosowane w oczach z niestabilnym aparatem więzadłowym w szerokim zakresie wskazań operacyjnych, zapewniając dobry efekt anatomiczny i poprawę funkcji

Słowa kluczowe: iris-claw, afakia, niestabilna torebka 


\section{ABSTRACT}

Background: Implantation of posterior chamber iris-claw intraocular lenses (IOLs)isoftenusedinthesurgicalmanagementofaphakiawithinadequatecapsular support. The purpose of the study was to evaluate the anatomical and functional outcomes and complication rate after implantation of a posterior chamber irisclaw aphakic IOL in eyes with insufficient capsular support.

Methods: This retrospective observational study comprised patients without adequate capsular support undergoing posterior iris-claw aphakic IOL implantation between 2016 and 2018.

Results: The study comprised 44 eyes of 44 patients. The mean follow-up was 12 months (range from 1 to 24 months). The IOLs were inserted during primary lens surgery in five eyes (11.36\%), during a posterior chamber IOL exchange procedure in 24 eyes (54.55\%), and as a secondary procedure in 15 aphakic eyes (34.09\%). The final mean best corrected visual acuity (BCVA) was significantly better than preoperatively $(0.49 \pm 0.33$ vs $0.36 \pm 0.26$, Snellen decimals) $(P<0.05)$. The most common complication after surgery was transient elevated intraocular pressure (10 eyes; 22.73\%).

Conclusions: The posterior chamber iris-claw aphakic IOLs provided good anatomical and functional outcomes and can be used for a wide range of indications in eyes without adequate capsular support.

Key words: iris-claw, aphakia, insufficient capsular support

\section{WSTĘP}

Soczewki mocowane do tęczówki (iris-claw), pierwotnie przeznaczone do korekcji krótkowzroczności podczas zabiegów chirurgii refrakcyjnej wewnątrzgałkowej, od wielu lat znajdują zastosowanie w korekcji bezsoczewkowości z niestabilną torebką [1]. Wykorzystywane są u pacjentów wymagających wymiany podwichniętego implantu tylnokomorowego, podczas operacji zaćmy z uszkodzonym aparatem więzadłowym soczewki oraz w czasie reoperacji po zabiegu usunięcia zaćmy powikłanym uszkodzeniem torby tylnej bez możliwości wszczepienia klasycznej soczewki tylnokomorowej. W zależności od przebiegu zabiegu wszczepiane są jednocześnie lub wtórnie, zwykle po 2-3 miesiącach od usunięcia zaćmy [2]. Obecnie najczęściej stosowanymi w afakii soczewkami iris-claw są implanty Artisan Aphakia (Ophtec) i Verisyse Aphakia (AMO). Mogą one być mocowane zarówno w przedniej, jak i tylnej komorze, a przy wyborze lokalizacji implantu zalecane jest uwzględnienie głębokości komory przedniej oraz gęstości komórek śródbłonka rogówki [3]. Główną alternatywą dla soczewek iris-claw w korekcji afakii z niestabilną torebką jest obecnie śródtwardówkowa fiksacja implantu polegająca na jego podszyciu lub zastosowaniu technik bezszwowych [4-8]. Zabiegi te zapewniają lokalizację implantu zbliżoną do fizjologicznej pozycji soczewki własnej, ponadto mogą być wykonane w sytuacji znacznego uszkodzenia tęczówki.

Zarówno w przypadku soczewek iris-claw, jak i implantów fiksowanych do twardówki opisane zostały powikłania po- operacyjne obejmujące m.in.: przemieszczenie implantu, wzrost ciśnienia wewnątrzgałkowego, krwawienie do ciała szklistego, torbielowaty obrzęk plamki (CME, cystoid macular edema) czy odwarstwienie siatkówki [9-14]. Z uwagi na nieskomplikowaną technikę oraz stosunkowo krótki czas zabiegu wielu chirurgów preferuje implanty iris-claw w korekcji bezsoczewkowości z uszkodzoną obwódką rzęskową lub torebką tylną $[15,16]$. Celem naszego badania była analiza retrospektywna efektów anatomicznych, funkcjonalnych oraz powikłań obserwowanych po zabiegach wszczepienia implantu iris-claw do komory tylnej, przeprowadzonych w Klinice Okulistyki Wojskowego Instytutu Medycyny Lotniczej (WIML) w Warszawie w latach 2016-2018.

\section{METODYKA}

Kryterium włączenia do badania stanowił okres obserwacji wynoszący co najmniej miesiąc. W badaniu analizowano dane obejmujące: rozpoznanie będące wskazaniem do wszczepienia soczewki iris-claw, wiek, płeć pacjenta, długość gałki ocznej, przebyte zabiegi chirurgiczne i urazy gałki ocznej oraz współistniejące choroby oczu i ogólnoustrojowe. U wszystkich pacjentów wszczepiono implant wykonany z polimetakrylanu metylu Artisan Aphakia (Ophtec BV, Holandia) o całkowitej długości 8,5 mm oraz średnicy części optycznej 5,4 mm (ryc. 1). Moc optyczna implantu obliczana była przy zastosowaniu formuły SRK/T za pomocą biome- 
tru optycznego IOL Master 500 (Carl Zeiss Meditec AG). Z uwagi na fakt, że implant wszczepiano do komory tylnej, zastosowano stałą A równą 116,9 (ryc. 2).

\section{RYCINA 1}

Implant wewnątrzgałkowy iris-claw Artisan Aphakia 205.

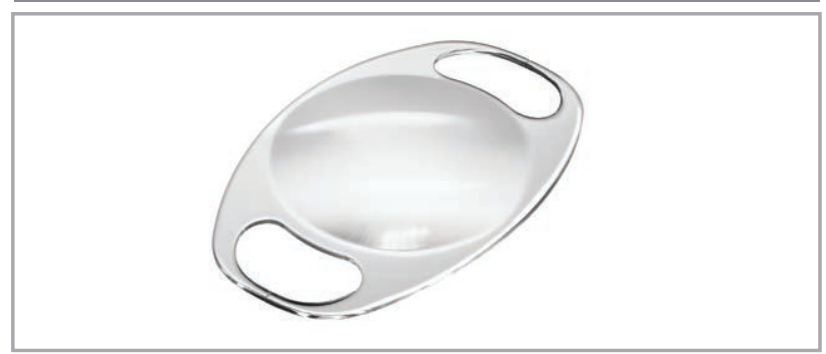

RYCINA 2

89-letni pacjent 24 miesiące po wszczepieniu implantu iris-claw do komory tylnej oka lewego.

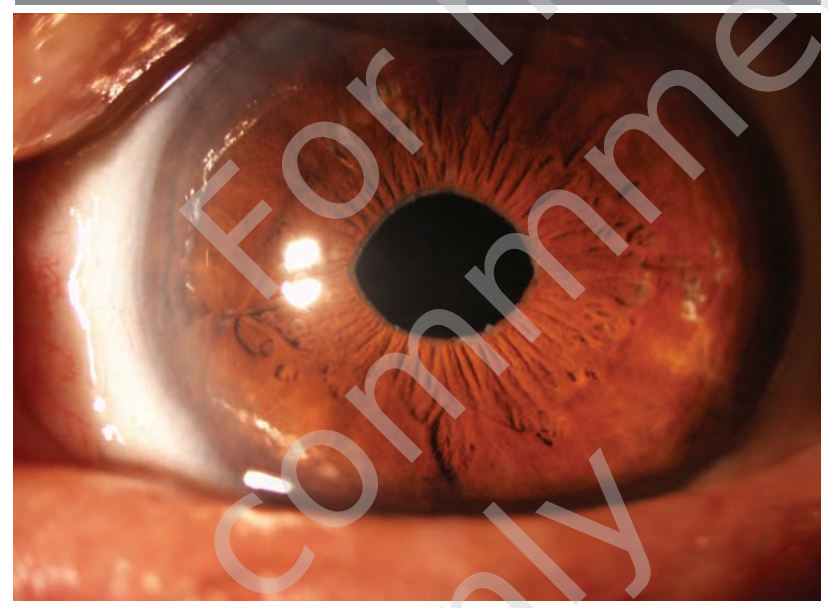

Ocenie poddano przed- i pooperacyjną najlepszą skorygowaną ostrość wzroku do dali (BCVA, best-corrected visual acuity) na tablicy Snellena, ciśnienie wewnątrzgałkowe (IOP, intraocular pressure), gęstość komórek śródbłonka, wartość ekwiwalentu sferycznego (SE, spherical equivalent) oraz błąd refrakcji, określony jako różnica pomiędzy refrakcją osiągniętą (ekwiwalentem sferycznym) a zamierzoną. Notowano wystąpienie powikłań śród- i pooperacyjnych. Ciśnienie wewnątrzgałkowe mierzono przy użyciu tonometru bezkontaktowego CT-800 (Topcon, Japonia). Gęstość komórek śródbłonka rogówki obliczano za pomocą mikroskopu lustrzanego CellChek SL (Konan, USA). Do pomiaru ekwiwalentu sferycznego stosowano autokeratorefraktometr KR-800 (Topcon, Japonia). Błąd refrakcji obliczano jako różnicę pomiędzy refrakcją osiągniętą (ekwiwalentem sferycznym) na koniec okresu obserwacji a refrakcją docelową wyznaczoną za pomocą biometru optycznego.
Wszystkie zabiegi implantacji sztucznej soczewki wewnątrzgałkowej typu iris-claw wykonane były w znieczuleniu okołogałkowym przez trzech doświadczonych chirurgów przy zastosowaniu tej samej techniki operacyjnej. Główne etapy zabiegu obejmowały kolejno: diatermokoagulację naczyń przyrąbkowych oraz wejście do komory przedniej w rąbku nożem $15^{\circ}$ od godziny 11.00 do 1.00 , potem wykonanie dwóch tunelowych portów bocznych na godzinach $2.00 \mathrm{i}$ 10.00 nożem $1,2 \mathrm{~mm}$, podanie wiskoelastyku do komory przedniej oraz wsunięcie sztucznej soczewki do komory przedniej, a następnie tylnej z enklawacją do tęczówki na godzinach 3.00 i 9.00. Następne etapy polegały na wykonaniu irydektomii przypodstawnej na godzinie 12.00, zszyciu rogówki w rąbku szwami pojedynczymi lub szwem ciągłym Nylon 10-0 i usunięciu wiskoelastyku układem aspiracyjno-irygacyjnym. Zabieg kończono podaniem do komory przedniej cefuroksymu $1 \mathrm{mg} / 1 \mathrm{ml}$ oraz wykonaniem iniekcji podspojówkowej deksametazonu. Szwy rogówkowe usuwano średnio po 3 miesiącach od zabiegu.

Do analizy statystycznej wykorzystano program Statistica 13.3 (Statsoft Polska). Zastosowano moduł statystyki opisowej oraz test kolejności par Wilcoxona, uznając wynik istotny statystycznie dla $\mathrm{p}<0,05$.

\section{WYNIKI}

W latach 2016-2018 w Klinice Okulistyki WIML wykonano zabieg implantacji soczewki iris-claw do komory tylnej w 48 oczach 48 pacjentów. Dwojga oczu nie włączono do badania ze względu na zbyt krótki okres obserwacji (< 1 miesiąca). Dwoje oczu wyłączono z badania ze względu na przebycie zabiegu wszczepienia implantu iris-claw połączonego z wykonaniem trabekulektomii (1 oko) lub pars plana witrektomii z podaniem oleju silikonowego do komory ciała szklistego (1 oko). Ostatecznie do badania retrospektywnego zakwalifikowano 44 oczu 44 pacjentów, którzy przebyli zabieg implantacji soczewki Artisan do komory tylnej. Średni czas obserwacji pacjentów zakwalifikowanych do badania wynosił 12,11 \pm 6,02 miesiąca (minimalny: 1 miesiąc, maksymalny: 24 miesiące). Tabela 1 przedstawia charakterystykę pacjentów pod względem demograficznym oraz obecności współistniejących chorób okulistycznych i ogólnoustrojowych.

W 24 oczach $(54,55 \%)$ wykonano, w ramach jednego zabiegu, wymianę implantu tylnokomorowego na soczewkę Artisan. W 15 oczach $(34,09 \%)$ z bezsoczewkowością pooperacyjną i niestabilną torebką został wykonany zabieg wtórnego wszczepienia implantu iris-claw. W 5 oczach $(11,36 \%)$ przeprowadzono zabieg usunięcia podwichniętej lub zwichniętej zaćmy z pierwotnym wszczepieniem soczewki Artisan. Zabieg wszczepienia implantu iris-claw połączony był z wykonaniem pars plana witrektomii w 4 oczach oraz wewnątrztorebkowym usunięciem soczewki w 1 oku. 


\section{TABELA 1}

Charakterystyka pacjentów pod względem demograficznym oraz obecności współistniejących chorób okulistycznych i ogólnoustrojowych.

\begin{tabular}{l|l}
$\mathrm{n}$ & 44 \\
\hline Kobiety/mężczyźni & $24 / 20$ \\
\hline Średni wiek \pm SD (lata) & $72,50 \pm 20,50$ \\
\hline Minimum-maksimum & $18-95$ \\
\hline Średnia długość gałki ocznej \pm SD (mm) & $23,40 \pm 1,77$ \\
\hline minimum-maksimum & $20,40-31,03$ \\
\hline Jaskra & $13(29,55 \%)$ \\
\hline Zespół pseudoeksfoliacji & $7(15,91 \%)$ \\
\hline Zwyrodnienie plamki żółtej & $5(11,36 \%)$ \\
\hline Uraz tępy gałki ocznej & $6(14,63 \%)$ \\
\hline Cukrzyca & $9(20,45 \%)$ \\
\hline Zespół Marfana & $2(4,55 \%)$ \\
SD (standard deviation) - odchylenie standardowe. &
\end{tabular}

Wskazania do wymiany implantu obejmowały podwichnięcie implantu tylnokomorowego - 22 oczu, zwichnięcie implantu tylnokomorowego do ciała szklistego - 1 oko oraz błonę wapienną na implancie podszytym śródtwardówkowo - 1 oko (ryc. 3). Podwichnięcie implantu tylnokomorowego dotyczyło 20 oczu z fiksacją dotorebkową wszczepu oraz 2 oczu z implantem podszytym śródtwardówkowo. Średni czas pomiędzy wszczepieniem implantu do torebki a jego wymianą na soczewkę Artisan wynosił 10,49 \pm 7,03 roku (minimalnie 5,53 miesiąca - maksymalnie 27,62 roku). W dwóch przypadkach przemieszczenia pod- szytego śródtwardówkowo implantu czas od jego podszycia do wymiany na soczewkę iris-claw wynosił odpowiednio 11 lat i 6 miesięcy oraz 12 lat i 11 miesięcy.
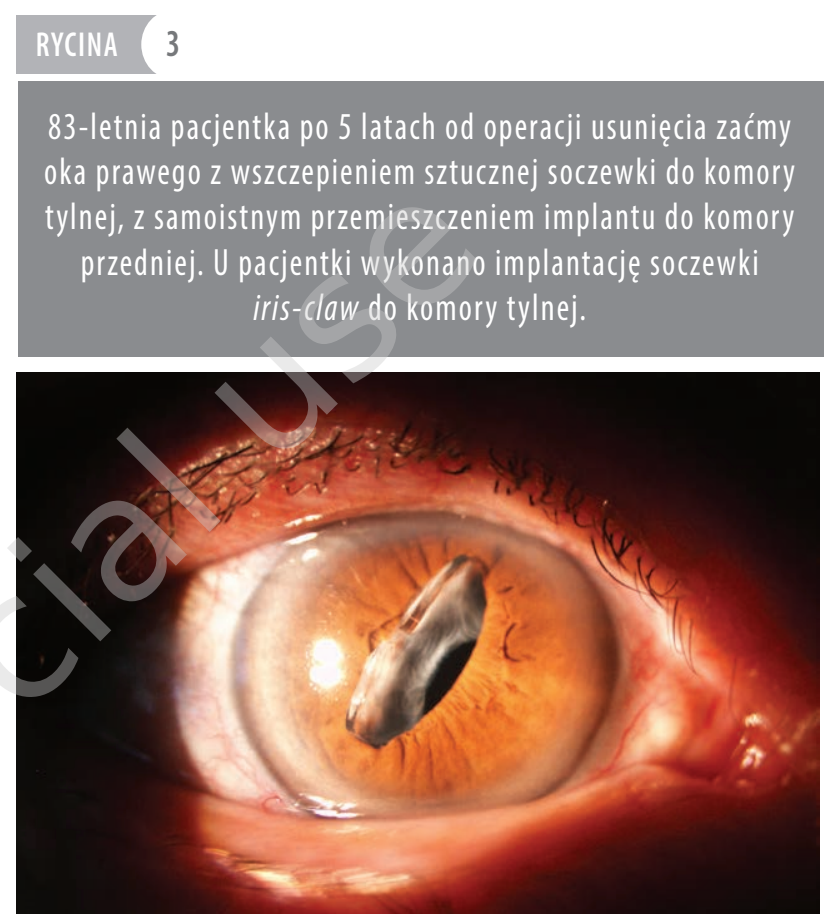

Afakia była rezultatem powikłanego zabiegu fakoemulsyfikacji zaćmy starczej w 12 oczach, usunięcia zaćmy pourazowej w 2 oczach oraz fakoemulsyfikacji podwichniętej

\section{TABELA 2}

Wyniki badań przeprowadzonych w 44 oczach przed zabiegiem i po zabiegu wszczepienia implantu iris-claw do komory tylnej. Wartość p dla testu kolejności par Wilcoxona.

\begin{tabular}{l|c|c|c} 
& Przed zabiegiem & Na koniec okresu obserwacji & p \\
\hline BCVA \pm SD (tablica Snellena) & $0,36 \pm 0,26$ & $0,49 \pm 0,33$ & 0,04 \\
\hline Minimum-maksimum & rppo $-1,0$ & rrpo $-1,0$ & \\
\hline Ekwiwalent sferyczny \pm SD (dioptrie sferyczne) & $5,66 \pm 5,61$ & $-0,19 \pm 1,58$ & 0,00 \\
\hline Minimum; maksimum & $-5,75 ; 15,25$ & $-4,75 ; 3,75$ & \\
\hline Ciśnienie wewnątrzgałkowe \pm SD $(\mathrm{mmHg})$ & $15,36 \pm 4,87$ & $15,07 \pm 4,10$ & 0,82 \\
\hline Minimum-maksimum & $7-31$ & $6-25$ & \\
\hline Gęstość komórek śródbłonka \pm SD $\left(\mathrm{mm}^{2}\right)$ & $2195,91 \pm 505,05$ & $2090,52 \pm 478,39$ & 0,07 \\
\hline Minimum-maksimum & $1532-3311$ & $1489-3257$ &
\end{tabular}

BCVA (best-corrected visual acuity) - najlepsza skorygowana ostrość wzroku do dali.

TABELA

Średnie wartości BCVA w trzech grupach wskazań do zabiegu.

\begin{tabular}{l|c|c|c} 
& $\begin{array}{c}\text { Wymiana implantu } \\
\text { tylnokomorowego }\end{array}$ & $\begin{array}{c}\text { Bezsoczewkowość } \\
\text { pooperacyjna }\end{array}$ & $\begin{array}{c}\text { Podwichnięta/zwichnięta } \\
\text { zaćma }\end{array}$ \\
\hline BCVA \pm SD przed zabiegiem & $0,37 \pm 0,25$ & $0,34 \pm 0,27$ & $0,40 \pm 0,32$ \\
\hline Minimum-maksimum & $0,02-1,0$ & $\operatorname{rrpo}-0,7$ & rrpo-0,8 \\
\hline BCVA \pm SD na koniec okresu obserwacji & $0,44 \pm 0,32$ & $0,47 \pm 0,34$ & $0,78 \pm 0,19$ \\
\hline Minimum-maksimum & rrpo-1,0 & rrpo-1,0 & $0,5-1,0$
\end{tabular}


zaćmy starczej w 1 oku. Wśród pacjentów z bezsoczewkowością średni czas od zabiegu usunięcia zaćmy starczej do wszczepienia soczewki Artisan wynosił 80,38 \pm 72,84 dnia (minimalnie 12 dni, maksymalnie 288 dni). Pierwotne wszczepienie implantu iris-claw wykonano po usunięciu zaćmy podwichniętej - w 3 oczach oraz z powodu pourazowego zwichnięcia zmętniałej soczewki własnej do ciała szklistego - w 2 oczach.

Nie odnotowano żadnych powikłań śródoperacyjnych podczas zabiegu wszczepiania soczewki iris-claw. Powikłania pooperacyjne obejmowały: owalizację źrenicy - 10 oczu (22,73\%), lokalny zanik zrębu tęczówki - 2 oczu (4,55\%), zapalenie tęczówki - 2 oczu (4,55\%), obecność barwnika na implancie - 3 oczu (6,82\%), wzrost ciśnienia wewnątrzgałkowego > $25 \mathrm{mmHg}$ - 10 oczu (22,73\%), hipotonia - 2 oczu (4,55\%), przemieszczenie implantu Artisan - 2 oczu (4,55\%), torbielowaty obrzęk plamki - 6 oczu (13,64\%), odwarstwienie siatkówki - 2 oczu (4,55\%), wylew krwi do ciała szklistego - 1 oko (2,27\%), zakrzep żyły środkowej siatkówki - 1 oko (2,27\%), zapalenie troficzne rogówki - 1 oko (2,27\%).

Najlepsza skorygowana ostrość wzroku do dali po zakończeniu okresu obserwacji poprawiła się w 26 oczach (59,10\%), pogorszyła się w 9 oczach $(20,45 \%)$ oraz pozostała bez zmian również w 9 oczach (20,45\%). Tabela 2 przedstawia średnie wartości skorygowanej najlepszej ostrości wzroku do dali, ekwiwalentu sferycznego, ciśnienia wewnątrzgałkowego oraz gęstości komórek śródbłonka przed zabiegiem i po zabiegu wszczepienia implantu iris- claw w 44 oczach objętych badaniem.

Średnia wartość SE w grupie 24 oczu, w których dokonano wymiany implantu tylnokomorowego na soczewkę iris-claw, wynosiła 1,56 \pm 3,21 Dsph przed zabiegiem oraz 0,45 $\pm 1,74$ Dsph po zabiegu. W grupie 15 oczu operowanych w celu korekcji bezsoczewkowości pooperacyjnej średnia wartość SE przed zabiegiem wynosiła 12,15 \pm 1,81 Dsph oraz $0,23 \pm 1,41$ Dsph po zabiegu. W pozostałych pięciu przypadkach, w których dokonano pierwotnego wszczepienia implantu Artisan, średnia wartość SE przed zabiegiem wynosiła $5,88 \pm 2,92$ Dsph, a po zabiegu - 0,70 $\pm 0,86$ Dsph. Tabela 3 przedstawia średnie wartości BCVA przed zabiegiem oraz na koniec okresu obserwacji w opisanych trzech grupach wskazań do zabiegu. W 40 oczach $(90,91 \%)$ błąd refrakcji (różnica między refrakcją osiągniętą a zamierzoną) na koniec okresu obserwacji zawarty był w granicach \pm 2 Dsph.

\section{DYSKUSJA}

Spośród wielu procedur chirurgicznych wykonywanych w celu korekcji bezsoczewkowości z niestabilną torebką obecnie stosowane są przede wszystkim fiksacja śródtwardówkowa implantu tylnokomorowego oraz soczewki iris-claw wszczepiane do przedniej lub tylnej komory oka [17]. Wybór implantów iris-claw pozwala na wykonanie zabie- gu w krótszym czasie w porównaniu z techniką śródtwardówkowego podszycia implantu, co może mieć wpływ na mniejszą traumatyzację tkanek oka, a tym samym profil bezpieczeństwa zabiegu $[18,19]$. Jednakże Wu Jing i wsp. w metaanalizie porównującej efekty wszczepienia soczewek iris-claw i śródtwardówkowego podszycia implantu tylnokomorowego w korekcji afakii z niestabilną torebką nie wykazali istotnej statystycznie różnicy w osiągniętej po zabiegu ostrości wzroku oraz częstości powikłań pooperacyjnych między analizowanymi technikami [17]. W celu ograniczenia utraty komórek śródbłonka rogówki wielu badaczy preferuje enklawację soczewki iris-claw w tylnej komorze oka ze względu na większą odległość implantu od śródbłonka rogówki niż w przypadku fiksacji w przedniej komorze [20-22]. Wyniki opublikowanych ostatnio prac nie potwierdzają jednak, aby enklawacja implantu iris-claw w przedniej komorze oka związana była z istotnie większą utratą komórek śródbłonka rogówki niż fiksacja w komorze tylnej [3, 23].

W naszym badaniu skorygowana najlepsza ostrość wzroku do dali po zakończeniu okresu obserwacji poprawiła się w 26 oczach $(59,10 \%)$, a w 40 oczach $(90,91 \%)$ błąd refrakcji na koniec okresu obserwacji był zawarty w granicach \pm 2 Dsph. Podobne wyniki opisali inni badacze w analizach retrospektywnych efektów wszczepienia implantu iris-claw do komory tylnej oka [16, 20, 24]. Odnotowaliśmy pogorszenie BCVA na koniec okresu obserwacji w 9 oczach (20,45\%) oraz brak zmiany BCVA także w 9 oczach (20,45\%). Przyczynami gorszej BCVA na koniec okresu obserwacji w naszym badaniu były: torbielowaty obrzęk plamki (3 oczu), odwarstwienie siatkówki (2 oczu), progresja zwyrodnienia plamki związanego z wiekiem (1 oko), zakrzep żyły środkowej siatkówki (1 oko), troficzne zapalenie rogówki (1 oko) oraz zapalenie błony naczyniowej (1 oko).

Częstość występowania CME po zabiegu wszczepienia implantu iris-claw do komory tylnej oka badacze opisują w zakresie 2,1-25\%, w zależności od wskazań do zabiegu oraz przebytych operacji oczu [3, 12, 20, 23, 25]. W naszym badaniu pooperacyjny CME rozwinął się w 6 oczach (13,64\%). W czterech przypadkach w leczeniu tego powikłania zastosowano iniekcje preparatu anty-VEGF (vascular endothelial growth factor) do ciała szklistego. Dwóch pacjentów nie wyraziło zgody na powyższe leczenie, co było powodem uzyskania na koniec okresu obserwacji gorszej BCVA niż przed zabiegiem. Pomimo zastosowania iniekcji preparatu anty-VEGF u jednego spośród czterech leczonych pacjentów nie uzyskano odpowiedzi na leczenie, a końcowa BCVA, w porównaniu z danymi przed zabiegiem, uległa pogorszeniu. $U$ pozostałych trzech leczonych pacjentów CME ustąpił po kilkukrotnym podaniu leku do ciała szklistego. W tych trzech przypadkach BCVA na koniec okresu obserwacji, w porównaniu z BCVA przed zabiegiem, poprawiła się (2 oczu) lub nie zmieniła się (1 oko). 
Odwarstwienie siatkówki w naszym badaniu wystąpiło u dwóch pacjentów, odpowiednio miesiąc oraz rok po zabiegu wszczepienia implantu iris-claw. Częstość występowania tego powikłania po implantacji soczewki iris-claw do komory tylnej oka badacze opisują w zakresie $0,3-3,2 \%$ $[15,23,26,27]$.

Po 18 miesiącach obserwacji, z powodu progresji postaci suchej zwyrodnienia plamki związanego z wiekiem, odnotowaliśmy osiągnięcie gorszej niż przed zabiegiem BCVA u 94-letniej pacjentki. W wykonanym badaniu optycznej koherentnej tomografii siatkówki stwierdzono poszerzenie strefy zaniku zewnętrznych warstw siatkówki w obszarze poddołkowym. W naszej opinii opisane zmiany nie były powiązane z implantacją soczewki Artisan. U pacjentki nie obserwowaliśmy żadnych powikłań pooperacyjnych.

W jednym przypadku odnotowaliśmy wystąpienie zakrzepu żyły środkowej siatkówki z obrzękiem plamki miesiąc po zabiegu wszczepienia implantu iris-claw. Powikłanie dotyczyło oka z wysoką nadwzrocznością, jaskrą pierwotną wąskiego kąta oraz retinopatią cukrzycową nieproliferacyjną. Pomimo leczenia obrzęku plamki za pomocą iniekcji anty-VEGF do ciała szklistego nie uzyskano poprawy ostrości wzroku.

Troficzne zapalenie rogówki dotyczyło 89-letniego pacjenta, u którego w przeszłości w operowanym oku występowały nawracające troficzne zapalenia rogówki. W leczeniu zastosowano m.in. preparaty wspomagające regenerację rogówki, terapeutyczne soczewki kontaktowe oraz zaklejenie powiek. Z powodu powstania zmętnień pozapalnych w obrębie nabłonka i istoty właściwej rogówki BCVA na koniec okresu obserwacji była gorsza niż przed zabiegiem. W naszym badaniu zapalenie przedniego odcinka błony naczyniowej wystąpiło w 2 oczach. Po zastosowaniu glikokortykosteroidów w postaci kropli do oczu w jednym przypadku zapalenie ustąpiło. U drugiego pacjenta doszło do rozwoju przewlekłego zapalenia przedniego odcinka błony naczyniowej, które było powodem uzyskania końcowej BCVA gorszej niż ostrość wzroku przed zabiegiem. Powikłanie to opisali również inni badacze [20,23].

Utrata komórek śródbłonka rogówki na koniec okresu obserwacji w naszym badaniu wyniosła średnio 4,80\%. W porównaniu z danymi sprzed zabiegu nie była to różnica istotna statystycznie. Gonnermann i wsp. w badaniu retrospektywnym pacjentów po wszczepieniu implantu iris-claw do komory tylnej oka opisali utratę komórek śródbłonka na poziomie 5,5\% w okresie obserwacji wynoszącym średnio 34 miesiące [25]. Wyniki większości badań wskazują na brak istotnej statystycznie różnicy w gęstości komórek śródbłonka przed enklawacją i po enklawacji implantu iris-claw do komory tylnej oka [21, 22, 26, 27].

W 10 oczach (22,73\%) odnotowaliśmy nieznaczną poziomą owalizację źrenicy na koniec okresu obserwacji. Powikła- nie to, opisywane także przez innych badaczy, może być rezultatem niesymetrycznej enklawacji części haptycznych implantu do zrębu tęczówki [20]. Stały kontakt haptyków $\mathrm{z}$ tęczówką może się wiązać $\mathrm{z}$ uwalnianiem ziaren barwnikowych ze zrębu tęczówki, które osadzając się na powierzchni implantu, mogą prowadzić do zaburzeń ostrości wzroku [21]. Wykonanie podspojówkowej iniekcji deksametazonu na koniec zabiegu może zredukować liczbę uwalnianych z tęczówki ziaren barwnika [28]. Schallenberg i wsp. opisali również atrofię zrębu tęczówki w miejscu enklawacji haptyków u 12,9\% pacjentów [15]. W naszym badaniu lokalny zanik zrębu tęczówki wystąpił tylko w 2 oczach (4,88\%), a obecność precypitatów barwnikowych na powierzchni implantu obserwowaliśmy w 3 oczach na ostatniej wizycie kontrolnej.

Obserwowaliśmy pooperacyjny wzrost IOP > $25 \mathrm{mmHg}$ w 10 oczach (22,73\%), podobnie jak w badaniu przeprowadzonym przez Morę i wsp. [23]. Po zastosowaniu leków hipotensyjnych w postaci kropli do oczu IOP uległo normalizacji w 8 oczach, natomiast w dwóch przypadkach konieczne było wykonanie trabekulektomii z powodu przetrwałego, wysokiego IOP. W obu przypadkach, w których przeprowadzono trabekulektomię, pacjenci byli leczeni od wielu lat z powodu jaskry wąskiego kąta przesączania, ponadto 1 oko cechowała wysoka nadwzroczność. Częstość występowania pooperacyjnej hipotonii po implantacji soczewki iris-claw do komory tylnej badacze opisują w zakresie 1,63-5,1\% [20, 25, 29]. W naszym badaniu przejściowe obniżenie IOP $<7 \mathrm{mmHg}$ po zabiegu wystąpiło w 1 oku (2,44\%).

W 2 oczach $(4,88 \%)$ odnotowaliśmy zwichnięcie implantu Artisan do ciała szklistego. W pierwszym przypadku powikłanie to wystąpiło u 18-letniego pacjenta 10 miesięcy po zabiegu. Implantacja soczewki iris-claw wykonana była w tym przypadku z powodu podwichnięcia implantu tylnokomorowego, który wszczepiono po usunięciu zaćmy pourazowej. W drugim przypadku zwichnięcie soczewki iris-claw do ciała szklistego nastąpiło miesiąc po zabiegu. Powikłanie dotyczyło oka niedowidzącego z oczopląsem i wysoką krótkowzrocznością. Zabiegu implantacji soczewki iris-claw dokonano $\mathrm{w}$ tym przypadku $\mathrm{z}$ powodu podwichnięcia implantu tylnokomorowego, który został wszczepiony po usunięciu zaćmy wrodzonej. Częstość przemieszczenia implantu iris-claw ufiksowanego na tylnej powierzchni tęczówki inni badacze opisują w zakresie $0-10 \%[14,16,20,26]$.

Rüfer i wsp. opisali wystąpienie wylewu krwi do ciała szklistego na poziomie $10 \%$ u pacjentów po fiksacji soczewki iris-claw do komory tylnej oka [14]. Jednak powikłanie to nie zostało odnotowane w innych pracach $[16,23,26]$. W naszym badaniu wylew krwi do ciała szklistego wystąpił w 1 oku i dotyczył pacjentki po przebytym zapaleniu wnętrza gałki ocznej, które miało miejsce 10 lat przed wszczepieniem implantu Artisan. Po zastosowaniu leków uszczel- 
niających naczynia krwionośne wylew krwi uległ całkowitej resorpcji bez pozostawienia trwałych następstw. Nie odnotowaliśmy żadnego przypadku nieszczelności rany pooperacyjnej ani zapalenia wewnątrzgałkowego, które zostały opisane przez innych badaczy [20].

\section{PODSUMOWANIE}

Głównymi ograniczeniami naszego badania są krótki okres obserwacji oraz mała liczba analizowanych przypadków. Pomimo że implanty iris-claw są obecnie powszechnie sto- sowane w korekcji bezsoczewkowości z niestabilną torebką, nadal nie ma zgodności co do tego, czy są bezpieczniejszą procedurą chirurgiczną niż śródtwardówkowa fiksacja implantu, szczególnie $\mathrm{w}$ aspekcie wystąpienia pooperacyjnego obrzęku plamki żółtej. Opisane przez nas wyniki funkcjonalne oraz powikłania po wszczepieniu implantów iris-claw dostarczają informacji pomocnych w kwalifikacji pacjentów do tego typu zabiegu.

\section{Źródło rycin: materiaty własne autorów.}

ORCID:

Ilona A. Kaczmarek - ID - https://orcid.org/0000-0003-0354-8437

\author{
ADRES DO KORESPONDENCJI \\ lek. Ilona A. Kaczmarek \\ Klinika Okulistyki, \\ Wojskowy Instytut Medycyny Lotniczej \\ 01-755 Warszawa, ul. Krasińskiego 54/56 \\ e-mail: ikaczmar@wiml.waw.pl
}

- Ilona A. Kaczmarek - ID - https://orcid.org/0000-0003-0354-8437

\section{Piśmiennictwo}

1. Worst JG, Massaro RG, Ludwig HH. The introduction of an artificial lens into the eye using Binkhorst's technique. Ophthalmologica. 1972; 164(5): 387-91.

2. Jezierski M, Kaczmarek I, Prost ME. Zastosowanie implantów soczewek wewnątrzgałkowych typu iris-claw u pacjentów z bezsoczewkowością. Ophtha Therapy. 2014; 4(4): 1-5.

3. Toro MD, Longo A, Avitabile T et al. Five-year follow-up of secondary iris-claw intraocular lens implantation for the treatment of aphakia: Anterior chamber versus retropupillary implantation. PLoS ONE 2019; 14(4): e0214140.

4. Stem MS, Todorich B, Woodward MA et al. Scleral-Fixated Intraocular Lenses: Past and Present. J Vitreoretin Dis. $2017 ; 1$ (2): 144-52.

5. Walia S, Kashyap S, Bhaisare V et al. Novel technique of sutureless glueless scleral fixated intraocular lens (SFIOL). Indian J Ophthalmol. 2019; 67(1): 64-8.

6. Can E. Flapless and sutureless intrascleral fixation of posterior chamber intraocular lens for correction of aphakia. J Cataract Refract Surg. 2018; 44(8): 929-31.

7. Dinc $E$, Vatansever $M$, Dursun Ö et al. Scleral fixated intraocular lens implantation with a modified Z-suture technique. Int Ophthalmol. 2018; 38(6): 2357-61.

8. Saleh M, Heitz A, Bourcier T et al. Sutureless intrascleral intraocular lens implantation after ocular trauma. J Cataract Refract Surg. 2013; 39(1): 81-6.

9. Wallmann AC, Monson BK, Adelberg DA. Transscleral fixation of a foldable posterior chamber intraocular lens. J Cart Refract Surg. 2015; 41(9): 1804-9.

10. Obeng FK, Vig VK, Singh P et al. Posterior Chamber Scleral Fixation of Intraocular Lenses in Post-Vitrectomised Aphakic Eyes. J Clin Diagn Res. 2017; 11(3): NC09-13.

11. Yang C, Chao Y. Long-term outcome of combined vitrectomy and transscleral suture fixation of posterior chamber intraocular lenses in the management of posteriorly dislocated lenses. J Chin Med Assoc. 2016; 79(8): 450-5.

12. Jayamadhury G, Potti S, Kumar KV et al. Retropupillary fixation of iris-claw lens in visual rehabilitation of aphakic eyes. Indian J Ophthalmol. Indian J Ophthalmol. 2016; 64(10): 743-6.

13. De Silva SR, Arun K, Anandan M et al. Iris-claw intraocular lenses to correct aphakia in the absence of capsule support. J Cataract Refract Surg. 2011; 37(9): 1667-72.

14. Rüfer F, Saeger M, Nölle B et al. Implantation of retropupillar iris claw lenses with and without combined penetrating keratoplasty. Graefes Arch Clin Exp Ophthalmol. 2009; 247(4): 457-62.

15. Schallenberg M, Dekowski $D$, Hahn A et al. Aphakia correction with retropupillary fixated iris-claw lens (Artisan) - long-term results. Clin Ophthalmol. 2014; 8: 137-41. 
16. Mohr A, Hengerer F, Eckardt C. Retropupillary fixation of the iris claw lens in aphakia. 1 year outcome of a new implantation techniques. Ophthalmologe. 2002; 99(7): 580-3.

17. Jing W, Guanlu L, Qianyin Z et al. Iris-Claw Intraocular Lens and Scleral-Fixated Posterior Chamber Intraocular Lens Implantations in Correcting Aphakia: A Meta-Analysis. Invest Ophthalmol Vis Sci. 2017; 58(9): 3530-6.

18. Teng $\mathrm{H}$, Zhang H. Comparison of Artisan iris-claw intraocular lens implantation and posterior chamber intraocular lens sulcus fixation for aphakic eyes. Int J Ophthalmol. 2014; 7(2): 283-7.

19. Hara S, Borkenstein AF, Ehmer A et al. Retropupillary fixation of iris-claw intraocular lens versus transscleral suturing fixation for aphakic eyes without capsular support. J Refract Surg. 2011; 27(10): 729-35.

20. Gonnermann J, Klamann MK, Maier AK et al. Visual outcome and complications after posterior iris-claw aphakic intraocular lens implantation. J Cataract Refract Surg. 2012; 38(12): 2139-43.

21. Baykara $\mathrm{M}$, Ozcetin $\mathrm{H}$, Yilmaz $\mathrm{S}$ et al. Posterior iris fixation of the iris-claw intraocular lens implantation through a scleral tunnel incision. Am J Ophthalmol. 2007; 144(4): 586-91.

22. Gicquel JJ, Guigou S, Bejjani RA et al. Ultrasound biomicroscopy study of the Verisyse aphakic intraocular lens combined with penetrating keratoplasty in pseudophakic bullous keratopathy. J Cataract Refract Surg. 2007; 33(3): 455-64.

23. Mora P, Calzetti G, Favilla S et al. Comparative Analysis of the Safety and Functional Outcomes of Anterior versus Retropupillary Iris-Claw IOL Fixation. J Ophthalmol. 2018; 2018: 8463569.

24. Schmidt I, Langenbucher A, Moussa S et al. Retroiridale Implantation einer VerisyseTM IrisklauenlinseRetroiridal implantation of a VerisyseTM iris claw lens. Der Ophthalmol. 2014; 112(3): 261-5.

25. Gonnermann J, Amiri S, Klamann M et al. Endothelial cell loss after retropupillary iris-claw intraocular lens implantation. Klin Monbl Augenheilkd. 2014; 231(8): 784-7.

26. Wolter-Roessler M, Küchle M. Correction of aphakia with retroiridally fixated IOL. Klin Monbl Augenheilkd. 2008; 225(12): 1041-4.

27. Forlini M, Soliman W, Bratu A et al. Long-term follow-up of retropupillary iris-claw Intraocular lens implantation: a retrospective analysis. BMC Ophthalmol. 2015; 15: 143.

28. Dick HB, Budo C, Malecaze F et al. Foldable Artiflex phakic intraocular lens for the correction of myopia: two-year follow-up results of a prospective European multicenter study. Ophthalmology. 2009; 116(4): 671-7.

29. Jayamadhury G, Potti S, Kumar KV et al. Retropupillary fixation of iris-claw lens in visual rehabilitation of aphakic eyes. Indian J Ophthalmol. 2016; 64(10): 743-6.

Wkład autorów:

Wszyscy autorzy w równym stopniu przyczynili się do powstania artykułu.

Konflikt interesów:

Nie wystęuje.

Finansowanie:

Nie występuje.

Etyka:

Treści przedstawione w artykule są zgodne z zasadami Deklaracji Helsińskiej,

dyrektywami EU oraz ujednoliconymi wymaganiami dla czasopism biomedycznych.
Authors' contributions:

All authors contributed equally to the article.

Conflict of interest:

None.

Financial support:

None.

Ethics:

The content presented in the article complies with the principles of the Helsinki Declaration, EU directives and harmonized requirements for biomedical journals. 